\title{
Nazhir Profesional Kunci Kesuksesan Wakaf Produktif
}

\author{
Murtadho Ridwan \\ Sekolah Tinggi Agama Islam Negeri Kudus \\ adle_hr@yahoo.com
}

\begin{abstract}
:
Nazhir in waqf activities does not constitute as one of its principles (rukn). But, in its execution or implementation of asset management, Nazhir has a central role. The development and decrease of waqf assets management depends on Nazhir. Nazhir has a strategic position and function in the management and development of waqf, therefore, the role of Nazhir is really needed anytime and anywhere. However nowadays there are many Nazhir that can not manage waqf well so a problem of consumptive waqf arises. To solve the problem; consumptive waqf should be changed to productive waqf, individual Nazhir should be changed to institutional Nazhir and traditional Nazhir should be changed to professional Nazhir. Actually professional Nazhir has an obligation to manage and maintain the waqf property. Professional Nazhir that recruited must have the ability of Islamic law, waqf law and modern business management. Thus Nazhir will be able to carry out its duties and obligation in managing waqf optimally in accordance with the expectations of Wakif. In conclusion professional Nazhir must have the capability of: human skill, human technical and human relation.
\end{abstract}

Keywords: productive waqf, professional nazhir, management

\section{Pendahuluan}

Ajaran wakaf sudah dikenal lama oleh semua peradaban umat manusia, dan biasanya berbentuk wakaf untuk tempat peribadatan yang dikelola oleh para pemuka agama. Dalam ajaran Islam, wakaf merupakan kegiatan filantropi yang berfungsi sebagai aset kontruksi pembangunan demi kesejahteraan masyarakat. Pada prinsipnya, wakaf merupakan anjuran kepada si kaya untuk memperhatikan orang-orang yang kurang mampu dengan cara mendermakan dana abadi yang dikelola, dan hasilnya dimanfaatkan untuk 
membantu kebutuhan, membina dan mengangkat derajat manusia.

Pada dasarnya, ajaran wakaf menuntut si pengelola (Nazhir) untuk memproduktifkannya. Ini tercermin pada hadis Ibnu Umar yang menyatakan: "Tahanlah pokok (modal)-nya dan sedekahkan hasilnya" (al-Nawawi, 1994: 11/88, hadis no. 4200). Sehingga tidak salah jika dikatakan bahwa wakaf adalah kegiatan yang mengandung unsur investasi masa depan dan pengembangan harta secara produktif untuk generasi yang akan datang. Semua bentuk harta wakaf menjadi saham, dan bagian dana investasi yang dapat memberikan hasil. Selain itu, wakaf juga mengandung unsur ibadah yang menjanjikan pada pelakunya (wakif) akan mendapat pahala secara berterusan.

Sejak masa Rasulullah bahkan sampai sekarang di negara-negara Islam harta wakaf berada di bawah tanggungjawab pemerintah sebagai Nazhir 'Am atau nazhir umum. Kemudian pemerintah dapat mengangkat Nazhir Khas atau nazhir khusus, baik berupa perseorangan maupun kelompok yang memenuhi syarat untuk mengelola harta wakaf di bawah pengawasannya. Nazhir Khas dituntut untuk bekerja profesional dalam mengelola dan menjaga harta wakaf sehingga dapat memberikan hasil yang bisa dimanfaatkan oleh pihak-pihak yang berhak (Mauquf 'alaih). Hal ini karena peran Nazhir pada masa sekarang ini semakin luas, tidak hanya menjaga dan melakukan halhal yang bersifat rutinitas, melainkan juga mencari inovasi-inovasi baru dalam rangka mengembangkan dan memberdayakan harta wakaf tersebut.

Problem mendasar perwakafan sekarang ini terletak pada manajemen pengelolaan yang telah bergeser dari jalan yang benar sehingga wakaf tidak sesuai dengan tujuan awal disyariatkannya. Untuk itu, perlu adanya upaya perbaikan yang bertujuan untuk membenahi manajemen wakaf dan menghilangkan keterpurukan manajemen wakaf akibat kelalaian atau buruknya manajemen yang diterapkan oleh Nazhir. Artikel ini akan berusaha mengeksploitasi peran Nazhir profesional dalam mensukseskan wakaf produktif.

\section{Wakaf Dalam Perspektif Ekonomi}

Monzer kahf menyebutkan bahwa wakaf memiliki dua dimensi, yaitu dimensi rohani (ibadah) dan dimensi jasmani (ekonomi). Dikatakan memiliki dimensi rohani karena wakaf adalah cabang ibadah yang dapat mendekatkan 
diri Wakif kepada Allah, sedangkan dimensi jasmani (materi) wakaf dapat dilihat dari segi ekonomi. Dari segi ekonomi, wakaf difahami sebagai usaha menjadikan harta dari kepentingan konsumsi menjadi modal investasi yang dapat menghasilkan manfaat dan faedah untuk kepentingan masa depan, baik untuk keperluan kelompok masyarakat ataupun keluarga (Kahf, 2000: 66).

Menurut sistem ekonomi Islam, wakaf memiliki tiga unsur penting dalam perekonomian sebagai berikut:

\section{a) Wakaf sebagai pengurang tingkat suku bunga (rate of interest)}

Salah satu ciri utama sistem ekonomi Islam adalah larangan riba dalam aktifitas ekonomi. Sedangkan bunga adalah salah satu unsur utama dalam sistem ekonomi konvensional dan sebagai penentu berlakunya sistem itu. Menurut ekonomi Islam, wakaf dapat mengurangi tingkat suku bunga secara nyata. Wakaf memiliki peran penting dalam mengurangi suku bunga, yaitu dengan menyediakan sarana publik yang diperlukan masyarakat tanpa membebankan biaya kepada pihak pemerintah. Hal ini dapat dilakukan dengan cara mobilisasi dana wakaf dari orang-orang kaya dan memanfaatkan dana tersebut untuk membangunkan sarana publik yang dibutuhkan masyarakat (Cizakca, 1997: 65).

Pada umumnya, sarana publik yang dibangun dengan dana wakaf berupa tempat ibadah (masjid dan mushalla), institusi pendidikan, sarana kesehatan dan juga kuburan. Sebagai contoh, masjid dapat dimanfaatkan masyarakat untuk melakukan solat berjama'ah dan kegiatan lain sehingga terwujudlah masyarakat yang harmonis. Sarana kesehatan untuk menolong orang-orang sakit dan memudahkan masyarakat dalam mendapatkan layanan kesehatan. Sedangkan institusi pendidikan dapat digunakan para pelajar untuk mencari ilmu pengetahuan sehingga tingkat pendidikan masyarakat dapat ditingkatkan. Dalam keadaan ini, fungsi wakaf yang amat penting menjadi nyata. Wakaf tidak hanya dapat membantu mengurangi anggaran belanja negara yang menyebabkan tingkat suku bunga naik, namun wakaf juga dapat mencapai tujuan ekonomi modern yang lain, yaitu menjadi salah satu mekanisme redistribusi kekayaan yang lebih baik dalam sistem ekonomi (Cizakca, 1997: 65). 


\section{b) Wakaf sebagai salah satu mekanisme redistribusi kekayaan (redistribution of wealth).}

Dalam sejarah Islam kita mengenal adanya perusahaan individu. Kita dapat mengamati bahwa sistem wakaf merupakan di antara yang dihasilkan perusahaan ini yang berfungsi sebagai salah satu mekanisme redistribusi kekayaan (redistribution of wealth) dalam ekonomi Islam. Sistem wakaf mampu mengurangkan ketidakmerataan distribusi pendapatan dan kemiskinan. Hal ini dapat dilakukan dengan memotivasi umat Islam untuk bersedekah jariah (wakaf) dengan janji akan mendapat pahala yang berkelanjutan sesuai dengan hadis Nabi.

Nilai-nilai ajaran Islam memotivasi penganutnya untuk mendistribusikan kembali kekayaan mereka kepada fakir miskin dan orang kurang mampu. Hasil penelitian Baskan menunjukkan bahwa Islam adalah jalan hidup yang dapat meningkatkan perilaku rendah hati pada penduduk Uthmaniyah di Turky (Baskan, 2002: 22). Dari sifat rendah hati itu, mereka termotivasi untuk bersedekah jariah (berwakaf) yang dapat membantu pemerintah dalam menyediakan sarana publik yang dibutuhkan masyarakat.

Meskipun teori ekonomi tentang redistribution menjelaskan bahwa redistibusi kekayaan yang didasarkan atas sifat individu seperti sifat rendah hati tidak dapat diandaikan dengan hasil yang optimal, namun hasil kajian Birol Baskan di negara Uthmaniyah menunjukkan bahwa masyarakat di kawasan itu telah terpenuhi keperluan hidupnya dengan sempurna dari sistem wakaf. Pemerintahan Uthmaniyah telah mewariskan klinik-klinik kesehatan, institusi pendidikan dan lembaga-lembaga NGO yang memiliki tugas mensejahterakan masyarakat yang seluruhnya dibangun dengan sistem wakaf (Baskan, 2002: 18). Sehingga tidak berlebihan apabila dikatakan: Sistem wakaf yang sudah ada di Uthmaniyah telah menyediakan segala sarana publik dengan tanpa membebankan biaya kepada pihak pemerintah. Dengan demikian kita dapat memandang sistem wakaf sebagai hasil kerjasama antara pemerintah dan individu untuk meningkatkan investasi.

\section{c) Mekanisme wakaf mengandung unsur investasi dan tabungan (saving).}

Dari penjelasan fungsi wakaf sebagai mekanisme yang dapat 
menurunkan tingkat suku bunga dan redistribusi kekayaan, dapat disimpulkan bahwa wakaf dari segi ekonomi merupakan tindakan yang menggabungkan antara investasi dan tabungan (saving). Ini karena wakaf sendiri adalah investasi, karena barang yang diwakafkan dapat menghasilkan manfaat dan faedah yang dibutuhkan masyarakat. Yang dimaksud investasi adalah menghasilkan keuntungan untuk dijadikan modal usaha lagi dan untuk digunakan memenuhi kebutuhan hidup. Definisi ini sesuai dengan pengertian wakaf (Muhyiddin, 2004: 30). Dana wakaf yang terhimpun dapat digunakan sebagai modal investasi masa depan untuk kepentingan generasi akan datang yang tidak mementingkan keuntungan dari pengelolanya sebab tujuan utama wakaf adalah untuk kebajikan dan ta'awun (Kahf, 2000: 70). Karena itu perlu ada Undang-undang yang mengatur harta wakaf di setiap negara untuk menjaga harta amanah umat itu dari kesewenang-wenangan orang yang tidak bertanggungjawab (Abu Zahrah, 1959: 32).

Harta wakaf dapat membantu aktifitas ekonomi sebuah negara, baik ia digunakan sebagai sumber modal pembangunan atau yang lain. Sifat kekal harta wakaf sangat membantu penyediaan modal tersebut. Dana wakaf dapat digabungkan dengan harta individu dan dijadikan modal usaha bagi perusahaan. Sebagian keuntungan usaha tersebut dapat diwakafkan berdasarkan gabungan modal usaha tersebut (Abd. Shakur bin $\mathrm{Hj}$. Borhan, 1994: 20). Selain itu harta wakaf dapat berfungsi sebagai pemacu pendapatan. Ini dapat dilihat apabila dana wakaf dipinjamkan kepada masyarakat dengan model al-Qard al-Hasan. Dengan skim ini, masyarakat Islam mampu menjalankan aktifitas ekonomi karena ia hanya melibatkan manajemen ke at as modal yang sudah ada. Secara tidak langsung wakaf berupaya mengurangi kemiskinan yang berlaku di masyarakat Islam dan dapat meningkatkan pendapatan negara sehingga terciptalah kesejahteraan sosial (Abd. Shakur bin $\mathrm{Hj}$. Borhan, 1994: 21).

\section{Pengalaman Pengelolaan Wakaf Produktif}

Sejarah telah membuktikan bahwa, tujuan wakaf untuk menciptakan kesejahteraan sosial sudah dicontohkan pada masa kejayaan Islam. Pada masa Daulah Bani Abbasiyah, wakaf telah dikembangkan sedemikian rupa sehingga menjadi sumber pendapatan negara. Ketika itu, wakaf yang pada 
awalnya meliputi berbagai aset seperti masjid, musola, institusi pendidikan, klinik kesehatan, lahan pertanian, rumah, toko, pabrik roti, bangunan kantor, gedung pertemuan, pusat perbelanjaan, pasar, gudang beras, dan lainnya pada akhirnya dapat diambil manfaatnya sebagai salah satu sumber pendapatan negara.

Apa yang berlaku pada masa Daulah Bani Abbasiyah itu masih dipraktikkan hingga sekarang di beberapa negara Islam sesuai dengan perkembangan zaman. Di negara seperti Mesir, Arab Saudi, Yordania, dan Turki, lembaga wakaf berkembang sangat pesat dan mampu memberi manfaat yang sangat besar. Bukan hanya untuk umat di negeri itu, namun juga untuk umat di negara lain karena ternyata ia mampu menjadi sarana pemberdayaan ekonomi yang cukup memadai bagi peningkatan kesejahteraan sosial, seperti pengembangan kegiatan dalam memajukan kebudayaan Islam, pemberian beasiswa, pembiayaan terhadap berbagai kegiatan penelitian, penyediaan sarana publik seperti klinik kesehatan, institusi pendidikan, kuburan dan lain sebagainya (Djamil, 2011: 33).

Di negara-negara seperti yang disebutkan, wakaf tidak hanya berupa harta tidak bergerak, tetapi juga berupa harta bergerak dan saham, yang semua itu dikelola dengan baik dan produktif, sehingga hasilnya dapat digunakan untuk mewujudkan kesejahteraan sosial masyarakat.

\section{a) Mesir}

Pada tahun 1971 pemerintah Mesir membentuk Badan Wakaf yang bertugas melakukan kerjasama dalam memeriksa peraturan-peraturan dan program-program pengembangan wakaf. Badan ini juga bertugas mengusut dan melaksanakan semua pendistribusian wakaf serta semua aktifitas perwakafan agar sesuai dengan tujuan yang telah ditetapkan. Badan ini juga menguasai pengelolaan wakaf dan memiliki wewenang untuk membelanjakan dengan sebaik-baiknya di mana pengembangannya sesuai dengan perundang-undangan Mesir No. 80 Tahun 1971. Lebih lanjut, Badan Wakaf ini berwenang untuk membuat perencanaan, mendistribusikan hasil wakaf setiap bulan dengan diikuti kegiatan-kegiatan yang bermanfaat, membangun dan mengembangkan lembaga wakaf, membuat laporan hasil kerja Badan itu kepada masyarakat. 
Untuk mengembangkan dan mengelola harta wakaf agar lebih produktif, Badan Wakaf menginvestasikan hasil harta wakaf di bank-bank Islam. Di samping itu, Badan Wakaf juga bekerjasama dengan sejumlah perusahaan, membeli saham dan obligasi perusahaan yang sehat dan memanfaatkan lahan-lahan pertanian yang terbiar. Badan Wakaf juga giat membangun sarana publik seperti klinik kesehatan, institusi pendidikan dan juga tempat ibadah sehingga tujuan sosial wakaf dapat tercapai (Abhats alNadwah Nahwa Daur Tanmawi li al-Waqf, 1993: 216-217).

\section{b) Arab Saudi}

Untuk mengawal kebijakan perwakafan, kerajaan Arab Saudi membentuk Majelis Tinggi Wakaf yang dipimpin langsung oleh Menteri Haji dan Wakaf dengan beranggotakan para ahli hukum Islam dari Kementerian Kehakiman, wakil dari Kementerian Ekonomi dan Keuangan, Direktur Kepurbakalaan serta tiga anggota lain dari kalangan cendekiawan dan wartawan.

Majelis Tinggi Wakaf Arab Saudi memiliki tugas dan wewenang yang telah ditetapkan pihak kerajaan sebagai berikut: (1) Mendata dan mengidentifikasi harta wakaf serta menentukan cara-cara pengelolaannya sesuai dengan kondisi masing-masing harta wakaf; (2) Menentukan kebijakan umum untuk penanaman modal, pengembangan dan peningkatan harta wakaf; (3) Mengetahui kondisi semua harta wakaf yang ada untuk mencari solusi dari permasalahan wakaf; (4) Membelanjakan harta wakaf menurut syarat-syarat yang telah ditetapkan wakif yang sesuai dengan syariah; (5) Menetapkan anggaran tahunan dan mendistribusikan hasil pengembangan wakaf sesuai standar skala prioritas; (6) Mengembangkan wakaf secara produktif dan mengumumkan hasil wakaf yang sudah dikeluarkan oleh kerajaan.

Dalam pengelolaan wakaf, Arab Saudi melakukan praktik langsung dengan menunjuk nazhir profesional. Nazhir bertugas membuat perencanaan dalam pengembangan harta wakaf, mensosialisasikan program yang telah disepakati, melaksanakan pendistribusian hasil wakaf kepada yang membutuhkan, memelihara dan mengawasi untuk keberlangsungan aset wakaf dan membuat laporan kepada kerajaan dalam pelaksanaan dan pengelolaan wakaf. Sedangkan dalam memanfaatkan hasil wakaf, Arab Saudi mengutamakan untuk memperbaiki dan membangun wakaf-wakaf yang sudah 
ada agar wakaf tersebut lebih produktif (Djunaidi dkk, 2008: 35-36).

\section{c) Yordania}

Undang-undang Yordania No. 25 Tahun 1947 tentang Wakaf Islam menyebutkan bahwa yang termasuk dalam urusan Kementerian Wakaf dan Urusan Agama Islam adalah wakaf masjid, madrasah, lembaga-lembaga Islam, rumah-rumah yatim, institusi pendidikan, lembaga-lembaga Syari'ah, kuburan-kuburan Islam, urusan-urusan haji dan urusan fatwa. Kemudian UU tentang Wakaf Islam tersebut diperkuat oleh UU No. 26 Tahun 1966 Tentang Wakaf. Pada pasal 3 secara rinci disebutkan bahwa tujuan Kementerian Wakaf dan Urusan Agama Islam antara lain adalah sebagai berikut (The Law of Jordan Kingdom No. 26/1966): (1) Memelihara masjid dan harta wakaf serta mengendalikan urusan-urusannya; (2) Mengembangkan masjid untuk menyampaikan risalah Nabi Muhammad SAW. dengan mewujudkan pendidikan Islam; (3) Membakar semangat jihad dan menguatkannya dalam kehidupan kaum muslimin; (4) Menumbuhkan akhlak Islami dan menguatkannya dalam kehidupan kaum muslimin; (5) Menguatkan semangat Islam, menggalakkan pendidikan agama dengan mendirikan lembaga-lembaga dan sekolah untuk menghafal al-Qur'an; (6) Mensosialisasikan budaya Islam, menjaga peninggalan Islam, melahirkan budaya baru Islam dan menumbuhkan kesadaran beragama.

Kementerian Wakaf dan Urusan Agama Islam juga diberi wewenang untuk membelanjakan hasil pengembangan wakaf sesuai rencana yang telah ditetapkan oleh Direktorat Keuangan. Pada tahun 1984, pendapatan yang dihasilkan dari pengembangan wakaf adalah; Hasil sewa diperkirakan mencapai 680 ribu Dinar Yordania, pendapatan dari tempat-tempat suci mencapai 120 ribu Dinar Yordania, pendapatan dari pabrik, rumah-rumah yatim dan industri di Yerusalem mencapai 80 ribu Dinar Yordania, dan pendapatan dari usaha lain mencapai 160 ribu Dinar Yordania (Djamil, 2011: 35).

\section{d) Turki}

Pada tahun 1925, harta wakaf Turki sudah mencapai tiga perempat dari luas lahan produktif di Turki. Wakaf di Turki dikelola oleh Direktorat Jenderal Wakaf. Sejauh ini ada dua pelayanan yang diberikan oleh Direktorat 
Jenderal Wakaf, yaitu pelayanan kesehatan dan pelayanan pendidikan dan sosial. Pelayanan kesehatan diberikan kepada masyarakat melalui wakafwakaf rumah sakit. Peran Dirjen Wakaf di Turki begitu besar dalam pengelolaan wakaf dengan terus mengembangkan harta wakaf secara produktif melalui upaya komersial dan hasilnya untuk kesejahteraan sosial. Usaha yang dilakukan Dirjen Wakaf Turkiey untuk memproduktifkan harta wakaf adalah dengan cara kerja sama dan investasi di berbagai lembaga, antara lain; Yvalik and Aydem Olive Oil Corporation, Tasdelen Healthy Water Corporation, Auqaf Guraba Hospital, Taksim Hotel (Sheraton), Turkish Is Bank, Ayden Textile Industry dan yang lain (Djunaidi dkk, 2008: 41).

\section{Peran Nazhir dalam Pengelolaan Wakaf Produktif}

Inti yang terkandung dalam ajaran wakaf menghendaki agar harta wakaf tidak dibiarkan tanpa ada hasil. Ini karena, semakin banyak hasil harta wakaf yang dapat dinikmati orang, akan semakin besar pula pahala yang mengalir kepada Wakif. Berdasarkan hal tersebut, pengembangan harta wakaf secara produktif merupakan kewajiban yang harus dilakukan oleh orang atau sekelompok orang yang dalam istilah fikih wakaf disebut Nazhir.

Nazhir adalah orang atau sekelompok orang yang bertanggungjawab untuk mengurusi, mengelola, menjaga dan mengembangkan harta wakaf. Nazhir dapat dilakukan oleh orang yang berwakaf (Wakif) sendiri atau orang lain yang ditunjuk oleh Wakif, atau mauquf 'alaih (orang atau pihak yang menerima manfaat atau hasil wakaf), atau oleh pemerintah apabila si Wakif tidak menunjuknya. Apabila Wakif menunjuk nazhir kepada beberapa orang secara berurutan, seperti: saya tunjuk si A menjadi nazhir wakaf saya, dan kalau dia meninggal supaya diganti si $\mathrm{B}$, dan kalau dia meninggal supaya diganti si C. Maka, penunjukan Wakif tersebut harus dipenuhi, (Hasan, 2011: 3).

Telah diriwayatkan (secara makna) bahwa Umar ibn Khaththab menjadi Nazhir harta wakafnya sendiri, lalu beliau berpesan agar yang menggantikannya sebagai nazhir selanjutnya adalah Hafshah (puterinya) selama masih hidup, dan seterusnya akan digantikan oleh orang-orang yang kompeten dari keluarganya (Abu Dawud, 2007: 2/88-89, hadis no. 2879). Dasar lain adalah sebuah kaedah yang menyatakan: "Syarat yang 
ditentukan Wakif bagaikan nash Syara' yang harus diikuti, selama tidak bertentangan dengan syari'ah (Al-Zuhaily, 1985: 8/178).

\section{a) Nazhir dalam tinjauan fikih}

Wakaf memiliki empat rukun, yaitu: (1) Wakif (orang yang berwakaf); (2) Mauquf 'alaih (pihak yang menjadi sasaran hasil wakaf, baik perorangan, sekelompok orang, atau institusi); (3) Mauquf (barang yang diwakafkan); (4) Shighat (pernyataan yang menunjukkan seseorang mewakafkan sebagian harta miliknya) (Al-Zuhaily, 1985: 8/159).

Meskipun para mujtahid sepakat tidak menjadikan Nazhir sebagai rukun wakaf, namun para ulama sepakat bahwa Wakif harus menunjuk Nazhir wakaf, baik yang bersifat perseorangan maupun kelembagaan (badan hukum). Pengangkatan Nazhir wakaf ini bertujuan agar harta wakaf tetap terjaga dan terurus sehingga harta wakaf tersebut tidak sia-sia.

Pada dasarnya siapapun dapat menjadi Nazhir sepanjang ia bisa melakukan tindakan hukum. Akan tetapi karena tugas Nazhir menyangkut harta benda yang manfaatnya harus disampaikan kepada pihak yang berhak menerimanya, maka mayoritas ulama Sunni menetapkan syarat-syarat Nazhir sebagai berikut (al-Zuhaily, 1985: 8/232): (1) Islam (al-Islam), Nazhir merupakan suatu jabatan (kekuasaan), maka tidak layak orang kafir memegang jabatan membawahi urusan orang muslim; (2) Adil (al-'Adalah), orang yang mampu menjaga diri dari perbuatan dosa besar dan atau membiasakan perbuatan dosa kecil, serta amanah (jujur) dan bertanggungjawab, sehingga tidak boleh mengangkat orang yang suka berbuat dosa dan tidak jujur untuk menjadi Nazhir; dan (3) Mampu (al-Kifayah), seorang Nazhir harus dapat melakukan tugas-tugas kenazhirannya secara professional dan kompeten. Untuk memenuhi syarat mampu ini, Nazhir harus berakal sehat dan juga dewasa. Jadi tidak sah apabila orang gila menjadi Nazhir dan tidak sah juga mengangkat anak kecil (belum dewasa) menjadi Nazhir.

Setelah seseorang sudah memenuhi syarat di atas dan diangkat menjadi Nazhir oleh Wakif atau pihak yang mewakili, maka ia memiliki tugas dan kewajiban. Menurut fikih, tugas dan kewajiban Nazhir secara global adalah melakukan segala hal yang berkaitan dengan perlindungan terhadap harta wakaf, penjagaan terhadap kemaslahatannya, pengembangan keman- 
faatannya dan membagikan hasil harta wakaf kepada yang berhak (alNawawi, 1996: 8/510, al-Zuhaily, 1985: 8/233). Secara rinci dapat diuraikan sebagai berikut: (1) Memberdayakan harta wakaf dengan melakukan penjagaan dan perbaikan untuk melindungi harta wakaf dari kerusakan dan kehancuran, agar tetap memberikan manfaat sebagaimana yang menjadi maksud wakaf tersebut; (2) Melindungi hak-hak wakaf dengan melakukan pembelaan atau advokasi dalam menghadapi sengketa hukum, atau penggusuran dan perampasan demi menjaga kelestarian dan kemanfaatan wakaf untuk kesejahteraan sosial; (3) Menunaikan hak-hak mauquf 'alaih dengan menyalurkan hasil wakaf kepada yang berhak dan tidak menundanya kecuali karena keadaan darurat atau ada alasan-alasan syar'i yang dibenarkan; (4) Melaksanakan syarat-syarat Wakif dan tidak boleh menyalahi syarat-syarat tersebut kecuali dalam situasi dan kondisi khusus yang sulit dihindari, seperti dalam penunjukan Nazhir perseorangan yang tidak mungkin dilakukan karena tidak memenuhi syarat kenazhiran.

Selain tugas dan kewajiban di atas, Nazhir dilarang melakukan halhal yang dapat menimbulkan fitnah dan kecurigaan, seperti berikut ini (Hasan, 2011: 7): (1) Menyewakan harta wakaf kepada dirinya sendiri atau keluarga dekatnya (anak-anak atau isterinya); (2) Menggadaikan harta wakaf atau meminjamkannya kepada orang lain yang tidak dijamin keamanannya, karena hal tersebut dapat menyebabkan lenyapnya atau rusaknya barang wakaf; (3) Bertempat tinggal di rumah atau tanah wakaf tanpa membayar sewanya, kecuali karena darurat atau alasan lain yang dapat dipertanggungjawabkan, seperti karena kemiskinan atau adanya bencana alam dan Nazhir membutuhkan penampungan sementara.

\section{b) Nazhir dalam tinjauan ekonomi}

Secara konsep fikih telah dijelaskan bahwa produktif dan tidaknya harta wakaf terletak pada profesional dan tidaknya Nazhir yang mengelola. Oleh sebab itu, untuk memproduktifkan harta wakaf, Nazhir harus menguasai Manajemen Mutu Terpadu (MMT) atau dalam istilah lain disebut dengan Total Quality Management (TMQ).

Manajemen Mutu Terpadu (MMT) diartikan dengan suatu konsep manajemen yang dikembangkan sebagai usaha peningkatan produktifitas 
serta peningkatan kualitas barang atau jasa harta wakaf. Hakekat MMT sebenarnya adalah filosofi dan budaya kerja organisasi yang berorientasi pada kualitas. Tujuan yang akan dicapai dalam organisasi termasuk Nazhir wakaf adalah memenuhi atau bahkan melebihi apa yang dibutuhkan dan yang diharapkan oleh pelanggan (Wakif dan Mauquf 'alaih). Sehingga dapat disimpulkan bahwa MMT merupakan satu pendekatan dalam menjalankan usaha yang mencoba untuk memaksimalkan daya saing organisasi lembaga pengelola wakaf melalui perbaikan terus menerus sehingga tercapai kemanfaatan harta wakaf yang diharapkan (Na'im, 2010: 26).

Sebagai lembaga filantropi Islam, sebuah lembaga wakaf harus mempunyai visi menjadi organisasi terpercaya yang selalu mengutamakan kepuasan donatur (Wakif) dan orang yang menerima manfaat dari harta wakaf yang dikelola (Mauquf 'alaih). Adapun misinya adalah memberikan pelayanan prima kepada donatur (Wakif) melalui program-program layanan donatur yang didukung jaringan kerja yang luas, sistem manajemen yang rapi serta SDM yang amanah dan profesional. Selain itu, lembaga wakaf harus memilki misi melakukan kegiatan pendayagunaan dana wakaf yang terbaik dan mengutamakan kegiatan pada sektor pendidikan, dakwah, kemanusiaan dan juga investasi karena dalam ajaran wakaf terkandung dimensi sosial dan ekonomi. Dan untuk mencapai visi dan misi tersebut diperlukan Nazhir profesional.

\section{c) Nazhir Profesional}

Dalam lembaga wakaf, Nazhir memiliki peran sebagai pemimpin umum lembaga tersebut. Nazhir memiliki tugas dan kewajiban berat dalam mengelola harta wakaf supaya tercapai kemanfaatan maksimal dan optimal sesuai dengan harapan Wakif secara khusus dan kaum Muslimin secara umum. Untuk itu diperlukan Nazhir profesional yang memiliki kemampuan human skill, human tehnical dan human relation yang mumpuni (Nafis, 2009).

Human skill berkaitan dengan keahlian Nazhir dalam bidang tertentu yang berkenaan dengan amanah untuk mengembangkan harta wakaf. Secara personal Nazhir haruslah orang-orang yang mempunyai reputasi dan kredibilitas moral yang baik, yaitu bersifat jujur, adil dan amanah. Pada tataran kompetensi keilmuan, seorang Nazhir harus menguasai ilmu-ilmu syari'ah, 
juga mesti menguasai materi-materi fikih muamalah, khusunya yang berhubungan dengan wakaf, Selanjutnya, pemahaman terhadap ilmu ekonomi, seperti keuangan, manajeman, akutansi, dan ilmu ekonomi Islam adalah suatu keharusan yang tidak bisa tidak harus dimiliki oleh Nazhir. Karena dengan pemahaman yang baik terhadap ilmu-ilmu tersebut seorang Nazhir mampu merealisasikan maksud dan tujuan dari wakaf produktif.

Kecerdasan Nazhir dapat diberi standar, seperti standar pendidikan yang tinggi (terdidik) sehingga seluruh proses yang dilakukan dapat menghasilkan produk yang baik dan tidak merugikan orang lain. Nazhir harus memiliki ketrampilan lebih, sehingga dapat memberikan produk yang berkualitas dan memiliki kelebihan dibandingkan orang lain.

Sedangkan human technical berkaitan dengan kemampuan untuk mengelola harta wakaf. Yaitu pengelolaan dengan prinsip keterbukaan (transparansi). Maksudnya, Nazhir mesti membeberkan informasi secara tepat waktu, memadai, jelas, akurat, dan dapat dibandingkan. Prinsip akuntabilitas ialah harus menetapkan tanggung jawab yang jelas dari setiap komponen organisasi selaras dengan visi, misi, sasaran usaha, dan strategi lembaga. Prinsip tanggung jawab (responsibility) ialah Nazhir harus memegang prinsip manajerial yang transaparan dan responsif. Prinsip tersebut harus dijalankan sesuai dengan ketentuan yang berlaku agar tetap terjaga kelangsungan usahanya. Prinsip independensi ialah Nazhir harus mampu menghindari terjadinya dominasi yang tidak wajar oleh stakeholders.

Nazhir juga tidak boleh terpengaruh oleh kepentingan sepihak. Ia harus bisa menghindari segala bentuk benturan kepentingan (conflict of interest). Misalnya, dalam mengelola wakaf secara produktif harta benda wakaf khususnya benda bergerak pasti mengandung risiko kerugian, bahkan kegagalan. Investasi dana wakaf di instrumen-instrumen investasi Islami seperti obligasi syari'ah ataupun pada saham-saham perusahaan Islami yang tergabung dalam Jakarta Islamic Index, mengandung market risk, yakni turunnya market value dari investasi tersebut. Penanaman modal langsung di sektor produksi, seperti agrobisnis, real estate, perindustrian, perdagangan dan pertambangan, masing-masing memiliki karakteristik risiko yang berbeda, baik dari segi risiko usahanya maupun risiko yang terkait dengan proses bisnis dan produksinya. 
Namun risiko bukan harus dihindari, justru harus dikelola agar potensi pengembangan dapat direalisasikan dengan memeperhitungkan dan mengendalikan risiko-risiko yang mungkin terjadi. Dengan kata lain, Nazhir berkewajiban menjalankan pengelolaan risiko (manajemen risiko) terhadap harta benda wakaf yang dipercayakan Wakif kepadanya. Manajemen risiko merupakan pilar penting dalam tata kelola organisasi yang baik (Good Corporate Governance), yang mutlak harus diterapkan dalam pelaksanaan pengembangan wakaf benda bergerak.

Manakala human relation adalah kemampuan Nazhir dalam membangun jaringan untuk kepentingan pengelolaan dan pengembangan wakaf. Pengembangan jaringan menjadi sesuatu yang asasi dalam mencapai tujuan produktif wakaf. Sebab tanpa jaring prinsip permintaan dan penyaluran (supply and demand) tidak dapat berjalan dengan stabil.

Jaringan (networking) dapat dibangun melalui kerjasama dengan pihak ketiga. Kerajasama dapat juga berbentuk kemitraan yang dibangun atas dasar saling menguntungkan, seperti investasi, membuka badan usaha, menggalang swadaya umat dan cara lain yang dapat membangun jaringan pemberdayaan wakaf produktif.

Untuk mencapai itu semua perlu membangun sinergi dan melakukan koordinasi, kerjasama dan konsultasi dengan pemerintah daerah, Kantor Kementerian Agama, Badan Wakaf Indonesia, organisasi keagamaan, kantor pertanahan dan instansi teknis terkait, investor dan bank syariah, lembaga pendidikan, lembaga keuangan syariah serta pihak-pihak lain yang terkait dengan program atau proyek tersebut. Dengan kerjasama ini diharapkan terbentuk sinergi lintas lembaga dan instansi terkait yang dapat mendukung keberhasilan pelaksanaan program pemberdayaan wakaf produktif. Sinergi ini akan terwujud jika masing-masing pihak yang bersangkutan dalam kondisi "balance", saling membutuhkan dan saling menghargai serta kesamaan persepsi dan motivasi terhadap program tersebut (Nurdin, 2011).

Jaringan kerjasama dalam program pemberdayaan wakaf produktif memiliki beberapa manfaat, diantaranya adalah sebagai berikut: (1) Meningkatkan kerjasama (increased collaboration); (2) Memanfaatkan sumberdaya secara bersama (resource sharing); (3) Memecahkan berbagai permasalahan secara bersama (problem solving); (4) Memberikan dukungan 
secara teknis secara lebih mudah (technical support); (5) Meningkatkan efisiensi (efficiency); dan (6) Meningkatkan hasil kerja yang lebih besar (greater output).

Ini karena, dalam jaringan kerjasama memiliki beberapa tujuan utama yang dapat dikelompokkan berikut ini: (1) Kajian dan pengelolaan (manajemen) wakaf secara profesional; (2) Pengembangan harta benda wakaf secara produktif; (3) Pemanfaatan harta benda wakaf secara maksimal untuk kepentingan umum; (4) Sosialisasi wakaf dan penggalakan kesadaran umat untuk berwakaf termasuk pengumpulan wakaf uang; dan (5) Pencarian investor yang bersedia diajak kerjasama dalam pengembangan wakaf produktif.

Jaringan kerjasama dengan berbagai pihak dalam pengembangan wakaf produktif bisa terealisasi jika: (1) Adanya kepentingan dan tujuan kerjasama yang sama; (2) Adanya keinginan untuk berbagi sumberdaya dan keahlian untuk menyelesaikan permasalahan secara bersama; (3) Adanya keinginan untuk saling menambah sesuatu yang saling bermanfaat, dan adanya hubungan timbal-balik; (4) Adanya pengertian bahwa kerjasama (networking) itu pada prinsipnya adalah system approach to management.

Dalam sejarah pengelolaan wakaf di Indonesia, majoritas harta wakaf dikelola oleh Nazhir tradisional sehingga harta wakaf tidak produktif. Agar sejarah pengelolaan wakaf di Indonesia tidak terulang, maka perlu ada perubahan paradigma. Yaitu dari pengelolaan yang bersifat konsumtif menuju pengelolaan yang bersifat produktif, dan dari Nazhir tradisional yang mendasarkan kepada kepercayaan semata menuju Nazhir profesional yang direkrut berdasarkan keahlian dalam bidang masing-masing. Dan juga memberdayakan dari Nazhir perseorangan menuju Nazhir kelembagaan agar mudah pertanggung jawabannya (Paradikma Baru Wakaf di Indonesia, 2008: 52).

Setelah ada perubahan paradigma tersebut, maka hal yang harus ditekankan dalam pengelolaan harta wakaf adalah transparansi dan akuntabilitas. Hal ini karena, harta wakaf bukan milik sebuah perusahaan, namun milik umat secara umum sehingga harus ada keterbukaan dalam mengelolanya. Harus lebih terbuka dan lebih melibatkan segala unsur umat dibandingkan dengan perusahaan publik. Artinya siapa saja umat Islam mempunyai hak dan sekaligus kewajiban untuk mengetahui secara detail tentang lalu lintas dana, pemasukan dan pengeluaran, serta jenis-jenis penggunaan sampai detail 
apa saja. Tidak ada alasan untuk menolak anggota umat untuk mengetahuinya. Selain itu, perlu ada "Audit Publik" sehingga pelakunya dapat dipertanggung jawabkan baik secara administratif maupun secara agama (duniaakhirat). Dengan cara seperti ini, ungkapan "harta wakaf sebagai dana umat" bukan hanya slogan saja, bukan pula untuk sekedar mengelabuhi umat, terlebih lagi untuk mengelabuhi orang-orang yang telah memberikan hartanya sebagai wakaf (Djamil, 2011: 31-32).

Melalui sistem Manajemen Mutu Terpadu (MMT), di samping taat pada ketentuan visi dan misi yang telah ditentukan, kerja Nazhir perlu dilaksanakan dengan transparansi pengalokasian dana untuk biaya administrasi atau manajemen, termasuk honorarium tenaga yang menjalankan administrasi atau manajemen secara profesional. Sudah barang tentu harus disadari bahwa bekerja dalam manajemen harta wakaf ini tidak identik dengan bekerja dalam perusahaan atau bisnis. Itulah sebabnya, ungkapan mengelola harta wakaf dengan modal ikhlas lillahi ta'ala dan semacamnya harus dikonstruksi ulang dan diperbaiki, baik dalam tampilan administratif maupun dalam pertanggung jawaban akhirat. Justru ungkapan tersebut memerlukan penanganan secara transparan dan profesional.

Tugas Nazhir profesional tidak terhenti sampai pada pengelolaan harta wakaf saja. Ia masih memiliki tugas untuk mendistribusikan hasil atau manfaat wakaf yang telah dikelola kepada pihak-pihak yang berhak menerimanya (Mauquf 'alaih). Nazhir harus membagikan hasil wakaf kepada para mustahik. Pembagian hasil wakaf harus dilakukan sesegera mungkin oleh Nazhir kecuali ada kebutuhan mendesak, seperti biaya perawatan harta wakaf atau melunasi kewajiban yang berkaitan dengan harta wakaf. Ini karena, hal-hal tersebut harus didahulukan ketimbang menyerahkan hasil wakaf kepada mustahik. Semua ketentuan pendistribusian hasil wakaf kepada para mustahik harus berdasarkan ketentuan yang dipersyaratkan Wakif (Adams, 2011: 46-47).

Pendistribusian manfaat hasil pengelolaan dan pengembangan harta wakaf dapat dilakukan secara langsung dan tidak langsung. Yang dimaksud dengan pendistribusian secara langsung adalah program pembinaan dan pemberdayaan masyarakat yang secara langsung dikelola oleh Nazhir. Hal ini dapat dilakukan apabila memenuhi persyaratan: (1) Program pembinaan 
dan pemberdayaan masyarakat dijalankan sesuai dengan syari'ah dan peraturan perundang-undangan, seperti program sosial dan umum berupa pembangunan fasilitas umum. Program pendidikan sekolah dengan biaya murah untuk masyarakat tidak mampu dan pelatihan ketrampilan. Program kesehatan berupa bantuan pengobatan bagi masyarakat miskin dan penyuluhan ibu hamil dan menyusui. Program ekonomi berupa pembinaan dan bantuan modal usaha mikro, penataan pasar tradisional dan pengembangan usaha pertanian dalam arti luas. Dan program dakwah berupa penyediaan da'i dan mubaligh, bantuan guru, bantuan bagi imam dan marbot masjid; (2) Tepat sasaran; dan (3) Berdampak pada pengurangan kemiskinan dan membuka lapangan pekerjaan.

Sedangkan yang dimaksud dengan pendistribusian secara tidak langsung adalah program pembinaan dan pemberdayaan masyarakat melalui kemitraan dengan lembaga pemberdayaan lain yang memenuhi kreteria kelayakan kelembagaan dan profesional. Hal ini dapat dilakukan melalui: lembaga pengelola zakat, baitul mal wa tamwil, lembaga kemanusiaan nasional, lembaga pemberdayaan masyarakat nasional, yayasan atau organisasi kemasyarakatan, dan lembaga lain baik berskala nasional maupun internasional yang melaksanakan program pembinaan dan pemberdayaan masyarakat sesuai dengan syari'ah dan peraturan perundang-undangan (Peraturan BWI No. 4 tahun 2010: Pasal 8-10).

\section{Penut up}

Pada hakekatnya wakaf bersifat produktif, hal itu sesuai dengan apa yang digariskan Rasulullah SAW ketika ditanya sahabat Umar tentang saham miliknya di tanah Khaibar. Rasulullah menjawab dengan singkat: "Tahan pokok (modal)-nya dan sedekahkan hasilnya". Jawaban itu memberi penjelasan bahwa harta wakaf merupakan modal investasi yang perlu dikelola dengan baik sehingga mendapatkan hasil yang dapat diambil manfaatnya.

Nazhir profesional yang memiliki human skill, human technical dan human relation yang mumpuni merupakan sosok pemimpin umum lembaga wakaf yang dapat mewujudkan tujuan wakaf. Dan sistem Manajemen Mutu Terpadu (MMT) merupakan salah satu cara yang harus dikuasai Nazhir 
Profesional untuk menjalankan tugas dan kewajibannya yang meliputi:

1) Meningkatkan kelayakan produksi harta wakaf hingga mencapai target ideal untuk memberi manfaat sebesar mungkin bagi tujuan wakaf, yaitu dengan cara meningkatkan hasil produksi dan investasi wakaf sebesar mungkin. Mengurangi sebesar mungkin pengeluaran dana untuk keperluan administrasi. Menghindari penyimpangan-penyimpangan, seperti kerusakan, pencurian, dan penyalahgunaan amanah.

2) Melindungi pokok-pokok harta wakaf dengan mengadakan pemeliharaan dan penjagaan yang baik dalam menginvestasikan harta wakaf dan mengurangi risiko investasi. Perawatan pokok harta wakaf dapat dilakukan dengan menginvestasikan harta wakaf pada investasi jangka panjang dan dengan cara membuat berbagai bentuk investasi.

3) Berpegang teguh pada syarat-syarat Wakif, baik berkaitan dengan jenis investasi maupun distribusi hasil harta wakaf.

4) Memberikan penjelasan kepada para Wakif dan mendorong mereka untuk melakukan wakaf baru. Serta memberi penyuluhan atau saran agar dibentuk lembaga wakaf yang profesional. Wallahu a'lam.

\section{Daftar Pustaka}

Abd. Shakur bin Hj. Borhan (1994), "Harta Wakaf Negeri Johor: Potensi ke Arah Pembangunan Ekonomi Umat Islam", Skripsi pada Fakultas Syariah Akademi Pengajian Islam Malaya University.

Abu Dawud, Sulaiman Ibnu al-Asy'ats al-Sijistani (2007), Sunan Abi Dawud, Kairo: Dar Ibnu al-Haitsam.

Abu Zahrah, Muhammad (1959), Muhadharat fi al-Waqf. Kairo: Matba'ah Ahmad 'Ali Mukhaymir.

Adams, Wahiduddin. (2011), "Signifikansi Peran dan Fungsi Nazhir Menurut Hukum Islam dan UU No. 41 Tahun 2004”, Jurnal al-Awqaf, vol. IV, No. 04, Januari 2011, hal. 37-48.Djunaidi, Achmad, dkk (2008), Menuju Era Wakaf Produktif, Depok: Mumtaz Publishing.

Baskan, Birol, (2002), "Waqf System as a Redistribution Mechanism in Ottoman Empire", Makalah Seminar di Department of Political Science Northwestern University, April 2002.

Cizakca, Murat (1997), "Towards Comparative Economic History of the Waqf System". Journal al Sajarah, vol. 2, no. 2, hal. 63-103. 
Depag RI (2008), Paradigma Baru Wakaf di Indonesia, Jakarta: Direktorat Pemberdayaan Wakaf Departemen Agama Republik Indonesia.

Djamil, Fathurrahman (2011), "Standarisasi dan Profesionalisme Nazhir di Indonesia", Jurnal al-Awqaf, vol. IV, No. 04, Januari 2011, hal. 2336.

Hasan, Tholhah, (2011), "Pemberdayaan Nazhir", Jurnal al-Awqaf, vol. IV, No. 04, Januari 2011, hal. 23-36.

Kahf, Monzer (2000), al-Waqf al-Islami: Tathawwuruh, Idaratuh, Tanmiyatuh. Libanon: Dar al-Fikr al-Mu'ashir.

Muhyiddin, 'Ali (2004), "Ahkam Istitsmar al-Waqf wa Ghillatuh", Majalah Iqtisad al-Islami, vol. 277, edisi Jun 2004, hal. 24-36.

Nafis, M. Cholil (2009), "Menjadikan Nazhir Sebagai Profesi Utama", www.bwi.or.id, diakses pada tanggal 11 Januari 2010.

Nawawi, Abu Zakariyya Yahya bin Syaraf al- (1994), Sahih Muslim bi Syarh al-Imam Muhyiddin al-Nawawi, Beirut: Dar al-Ma'rifah.

(1996), Raudah al-Thalibin, Kairo: al-Maktab al-Islami li alThaba'ah wa al-Nasyr.

Peraturan Badan Wakaf Indonesia No. 4 Tahun 2010 Tentang Pedoman Pengelolaan dan Pengembangan Harta Benda Wakaf.

The Law of Jordan Kingdom no.26/1966, Management of Awqaf, Holy building and Islamic affairs.

Wizarah al-Awqaf wa al-Syu'un al-Islamiyah (1993), Abhats Nadwah: Nahwa Daur Tanmawi li al-Waqf, Kuwait: Markaz Abhats al-Waqf wa alDirasat al-Iqtishadiyah. 